\title{
EFFECT OF EPIDIDYMAL ISOLATION ON THE PROTEIN COMPONENT OF BULL EPIDIDYMAL TISSUE
}

\author{
H. F. S. HUANG, ${ }^{*}$ T. T. TURNER $\uparrow$ AND A. D. JOHNSON
}

Department of Animal Science, University of Georgia, Athens, Georgia 30602, U.S.A.

(Received 3rd December 1974)

\begin{abstract}
Summary. Four fractions of protein from intact and 'isolated' bull epididymides were extracted. The total extractable protein was increased by isolation mainly due to increases in the lipoprotein and DNA-protein fractions. Changes of lipoprotein may be associated with the increase of lipid which also occurs in isolated tissue. This may reflect the increase of pentose cycle activity and lipogenesis due to the absence of spermatozoa in the epididymal tubules. Changes of DNAprotein may indicate a change of protein metabolism. Electrophoresis of protein fractions showed that individual proteins may be changed by the zonal origin of the epididymal tissue and the presence or absence of spermatozoa in the epididymal tubules.
\end{abstract}

\section{INTRODUGTION}

Many workers have reported that the absence of spermatozoa in the epididymis can alter the physiological process of epididymal tissue. After isolation of the epididymis from the testis, there is a decrease in the respiratory and glycolytic activities of mouse epididymal tissue (Elliot, 1965), an increase in the total lipid of rat epididymal tissue (Turner \& Johnson, 1971), a reduction in the utilization of labelled glucose and fructose and other organic compounds (Turner \& Johnson, 1973a, b), changes in steroid metabolism by bull epididymal tissue (R. R. Evans and A. D. Johnson, unpublished data), and some change in the epididymal plasma protein of the rat (Huang \& Johnson, 1975).

The purpose of the present study was to investigate the protein component of different zones of bull epididymal tissue and to determine the effect of epididymal isolation on these protein components.

\section{MATERIALS AND METHODS}

The preparation of sperm-free 'isolated' epididymal tissue by ligation and severance of the efferent ducts, and the zonation of the bull epididymal tissue has been reported previously (Turner \& Johnson, 1973a). Zones 1 and 2

* Present address: Department of Obstetrics and Gynecology, College of Physicians and Surgeons, Columbia University, 630 W. 168th Street, New York, New York 10032, U.S.A.

$\dagger$ Present address: Department of Obstetrics and Gynecology, The University of Texas, Health Science Genter at San Antonio, 7703 Floyd Curl Drive, San Antonio, Texas 78284, U.S.A. 
constitute the caput epididymidis, Zone 3 the corpus, and Zones 4 and 5 the cauda epididymidis. Tissues from the intact and 'isolated' epididymides of each of five bulls were used in the study.

The tissues were homogenized and freeze-dried. The various protein fractions were extracted according to the method described by Lavon, Volcani \& Danon (1971); lipoprotein was extracted with $0.1 \mathrm{~N}-\mathrm{NaOH}$, acid-soluble protein with $0.1 \mathrm{~N}-\mathrm{HCl}$, keratin-like basic protein with $0 \cdot 1 \mathrm{~N}-\mathrm{HCl}$ after treatment with $3 \%$ mercaptoethanol, and the DNA and its associated proteins with $3 \%$ $\mathrm{NaOH}$. Protein levels in each extraction fraction were determined by the Folin reagent method (Lowry, Rosebrough, Farr \& Randall, 1951).

Protein fractions were separated by acrylamide disc gel electrophoresis at basic and acidic pH following the method of Davis (1964) and Reisfeld, Lewis \& Williams (1962). The amount of protein applied to each gel was 300 to $400 \mu \mathrm{g}$. At pH 8.8, a current of $5 \mathrm{~mA} / \mathrm{gel}$ was applied for approximately $1 \mathrm{hr}$, with bromophenol blue as a front marker, and at $\mathrm{pH} 4.4,7 \mathrm{~mA} /$ gel were applied for approximately $2 \mathrm{hr}$ with methyl green as the front marker. After electrophoresis, the gels were stained with $1 \%$ aniline blue in $7 \%(\mathrm{v} / \mathrm{v})$ acetic acid for $1 \mathrm{hr}$. They were then differentiated in an automatic de-stainer containing 7\% acetic acid. Student's $t$ test was used to compare the difference between the control and the sperm-free tissue.

\section{RESULTS}

The TEP level of the control and the sperm-free tissues (Text-fig. 1a) tended to decrease from Zone 1 to Zone 3 and then to increase in Zones 4 and 5 . The TEP of the sperm-free tissues was higher than that of the respective control tissues, but the differences were significant only in Zones 3 and $5(P<0 \cdot 05)$.

In control tissues, the lipoprotein (Text-fig. Ib) was low in Zones 1 and 2, highest in Zone 3 and tended to decrease in Zones 4 and 5. After epididymal isolation, lipoprotein levels increased and significant differences between control and sperm-free tissues were observed in Zones 1 and $2(P<0.05)$.

Acid-soluble protein levels (Text-fig. 1c) were lowest in Zone 1 and similar in the other zones; isolation had no significant effect.

In the control tissues, the keratin-like basic protein tended to decrease from Zone 1 to Zone 3 and then to increase in Zones 4 and 5 (Text-fig. 1d). 'Isolation' led to an increase in Zones 1 to 4 , but the differences were not significant.

The level of DNA and associated protein in the control tissue decreased from Zone 1 to Zone 3, and then increased to a maximum in Zone 5 (Text-fig. 1e). After 'isolation', there was an increase in Zones 3 and 5, and a decrease in Zones 1, 2, and 4. A significant difference between control and 'isolated' tissues was found in Zones 1 and $5(P<0.05)$.

\section{Electrophoresis of protein fractions}

Twenty-two protein bands of the lipoprotein fraction were identified according to electrophoretic mobility after electrophoresis at $\mathrm{pH} 8 \cdot 8$ (Text-fig. 2a). Most of the bands were present in all epididymal zones, but some were present only in certain portions of the epididymis. Band 6 was identified only in Zones 


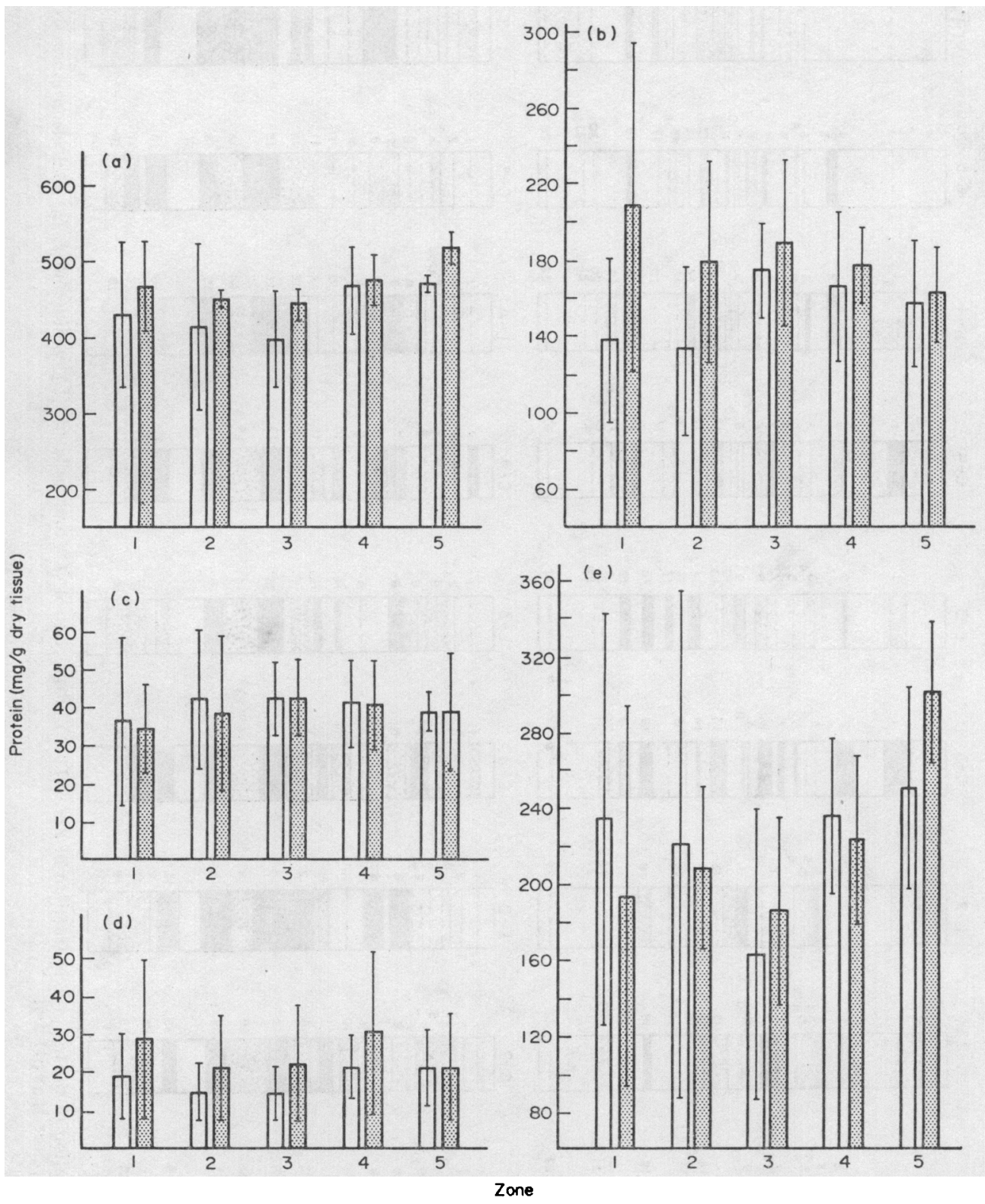

TEXT-FIG. 1. Comparison of the protein levels in the various zones of the epididymides of five bulls in each of which one epididymis was intact (open columns) and one epididymis was 'isolated' from the testis (stippled columns) by ligation and severance of the efferent ducts. The vertical bars represent the S.E.M. (a) Total extractable protein (TEP); (b) lipoproteins; (c) acid-soluble proteins; (d) keratin-like basic proteins; (e) DNA and associated proteins. 

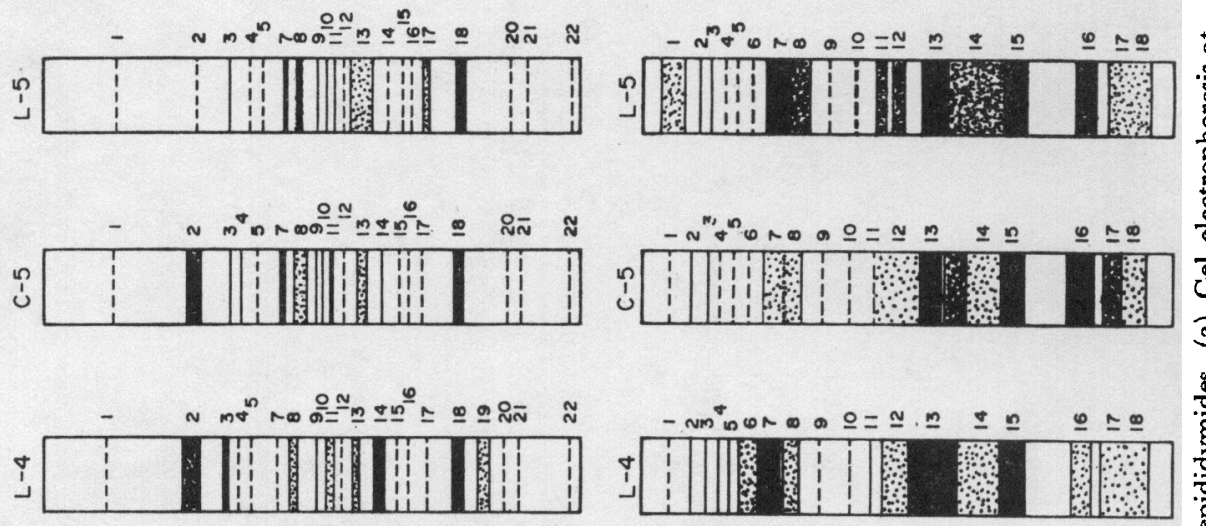

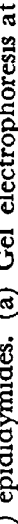
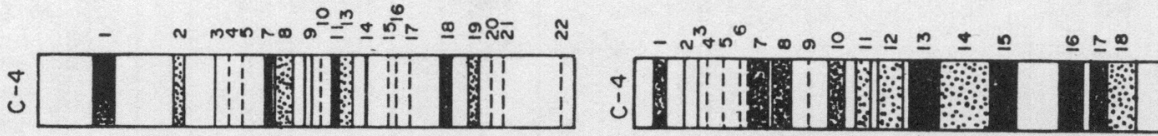

3
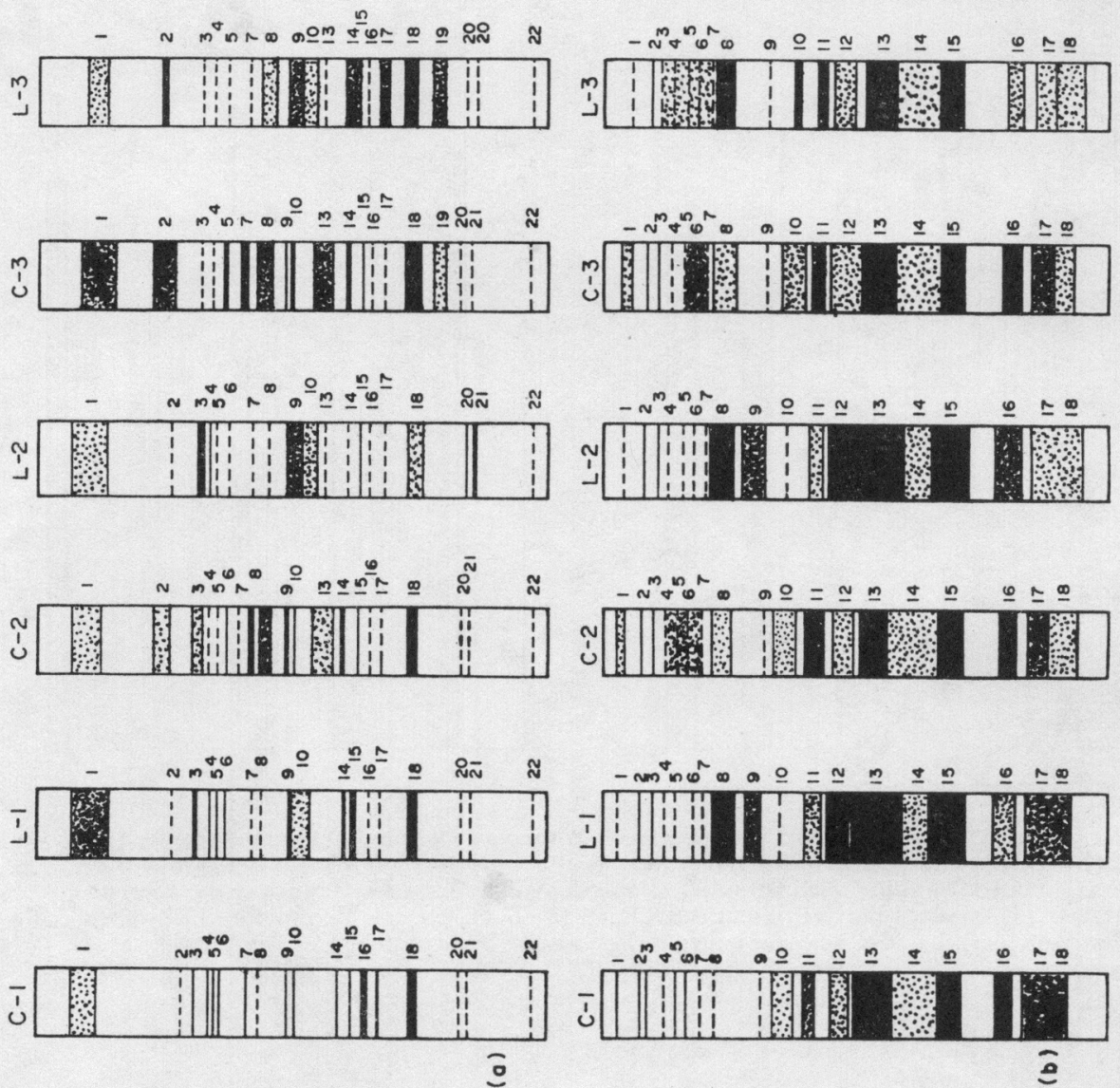

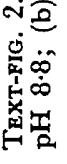



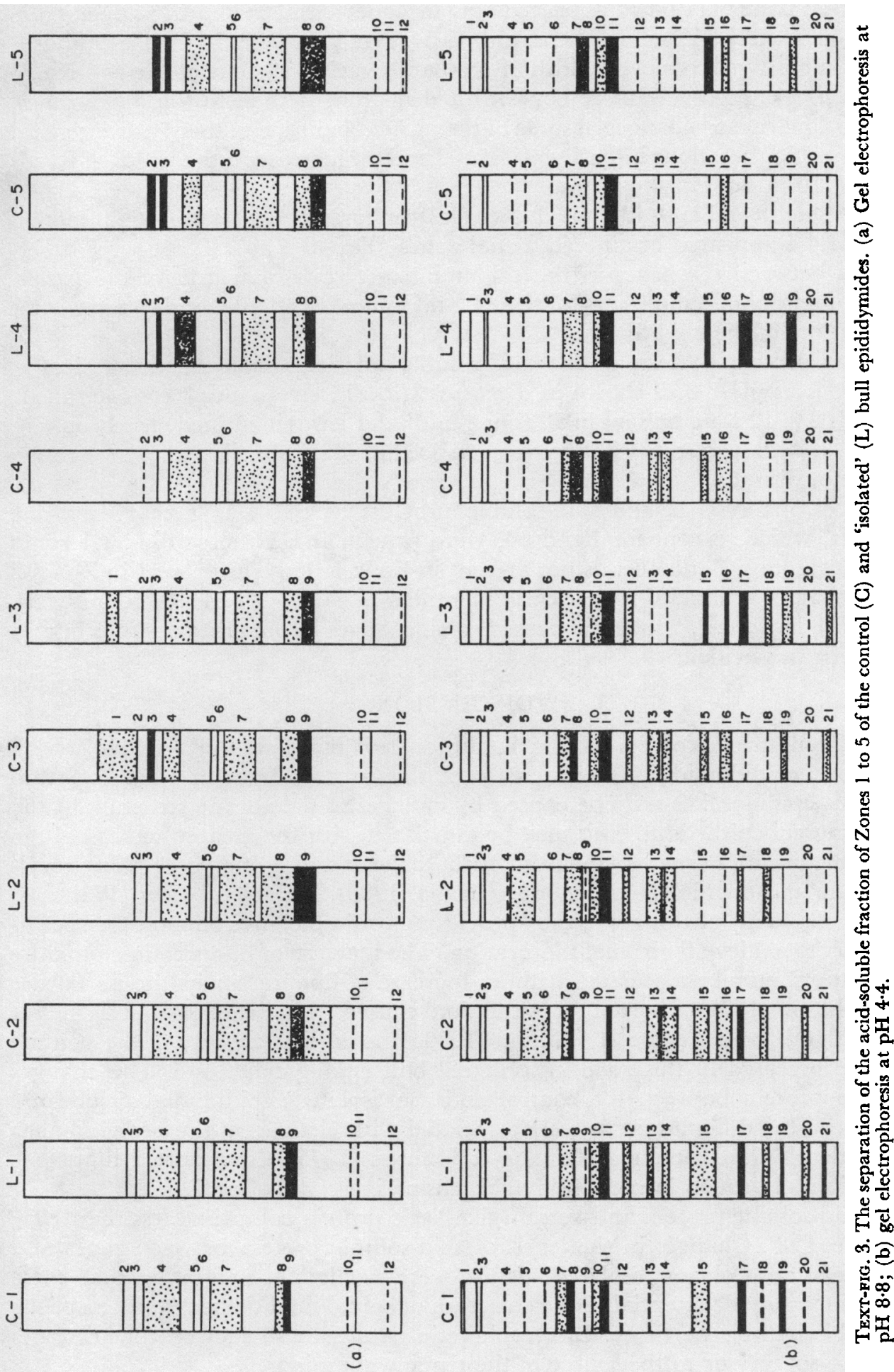

mi 
1 and 2; Bands 11 and 12 appeared only in Zones 4 and 5; Band 13 appeared in all zones except Zone 1; and Band 19 was only present in Zones 3 and 4. The intensity of colour or width of the bands varied in some of the zones, e.g. Band 2 was relatively more concentrated in Zone 3 than in the other zones. 'Isolation' caused changes in some of the protein bands, e.g. there was a general decrease in the colour intensity of Band 2 and an increase in the width of Bands 9 and 10 in most of the zones.

The eighteen bands identified after electrophoresis of the lipoprotein fraction at $\mathrm{pH} 4.4$ appeared in all epididymal zones (Text-fig. 2b). There were differences between the zones in the colour intensity and/or widths of the bands. The intensity of Band 9 was increased, and that of Band 10 was decreased after 'isolation' of the epididymis.

The protein pattern of the acid-soluble fraction, determined by electrophoresis at $\mathrm{pH} 8 \cdot 8$, is shown in Text-fig. 3(a). Twelve bands were identified; Bands 2 to 12 were present in all zones, but Band 1 was identified clearly only in Zone 3. Although some changes were noticed in the 'isolated' tissue, the change was not distinct.

Electrophoresis of the acid-soluble proteins at $\mathrm{pH} 4 \cdot 4$, gave twenty-one bands, which, except for Band 16, were present in all the epididymal zones (Text-fig. $3 \mathrm{~b}$ ). Band 16 was not present in Zone 1 , but was present in Zones 2 to 5 . Bands 4, 5 and 6 were clearly identified in Zones 1, 3, 4 and 5, but were obscure in Zone 2. 'Isolation' caused some changes in the protein bands but no pattern was evident.

\section{DISGUSSION}

The highest level of lipoprotein in the control tissue was present in Zone 3 (corpus epididymidis). The increase of this protein fraction from caput to corpus epididymidis may be caused by changes of membrane structure of the epididymal epithelium. This may be associated with the greater activity of the pentose cycle (Turner \& Johnson, 1973a), the increase of glycerylphosphorylcholine and certain inorganic ions (Crabo, 1965), and blood flow (Waites \& Setchell, 1969) of this zone, thus providing a suitable environment for spermatozoa to achieve their final maturation. The increase of lipoprotein caused by. 'isolation' may be associated with an increase of lipoprotein synthesis. Turner \& Johnson (1971) reported that 'isolation' caused an increase of lipid in the rat epididymis, and Turner \& Johnson (1973a) noted that activity of the pentose cycle increased in this zone in 'isolated' bull epididymal tissue. The changes of lipoprotein between the control and the 'isolated' epididymal tissues and between the different zones were associated with changes in the protein bands revealed by electrophoresis. Huang \& Johnson (1975) also reported that some fractions of protein in rat epididymal plasma increased after 'isolation'.

Acid-soluble protein and keratin-like basic protein comprised less than $10 \%$ of the TEP. Changes in the levels of acid-soluble protein between zones and between control and 'isolated' tissues were negligible, suggesting that these fractions may be essential to the structure of epididymal tissue regardless of the zonal origin of the tissue. Electrophoretic patterns also showed that changes due to surgery or to the source of the tissue were minor. 
In the present study, DNA and its associated proteins comprised about $50 \%$ of the TEP. Dawson \& Scott (1964) and Lavon et al. (1971) reported that the DNA content in sperm cells does not change significantly during the maturation process in the epididymal duct. This suggests that the change of DNA and associated protein level in the different portions of the bull epididymis reported here was mainly caused by the differences in the epididymal tissue. The high level of DNA and associated protein in the caput and cauda epididymidis suggests very active protein synthesis in these areas. This may be associated with the production of proteins which are responsible for the resorption of testicular fluid in the caput epididymidis, as reported by Nicander (1965), Barker \& Amann (1971) and Orgebin-Crist (1969). In the cauda epididymidis, the DNA and associated protein may be related to the resorption or dissolution of spermatozoa (Orgebin-Crist, 1969). The change of this fraction caused by 'isolation' cannot be explained at this time. It is possible that the absence of spermatozoa in the lumen of the epididymal tubules causes certain portions of the tissue (Zones 1, 2 and 4) to reduce their protein synthesis or causes substances to accumulate in other portions of the epididymis (Zones 3 and 5).

The results of the present study suggest that the protein components of different portions of the epididymis are different and are altered by the presence or absence of spermatozoa in the lumen of the epididymal tubules. The results further suggest that different portions of the epididymis have a specific protein environment which may provide a different but more suitable environment for the spermatozoa at various stages of maturation.

\section{REFERENCES}

Barker, L. D. S. \& AMANn, R. P. (1971) Epididymal physiology II. Immunofluorescent analyses of epithelial secretion and absorption and of bovine sperm maturation. F. Reprod. Fert. 26, 319-332.

CRABo, B. (1965) Studies on the composition of epididymal content in bulls and boars. Acta vet. scand. 6, Suppl. 5.

Davis, B. J. (1964) Disc electrophoresis. II. Method and application to human serum proteins, Ann. N.Y. Acad. Sci. 121, 404-427.

Dawson, R. M. C. \& ScotT, T. W. (1964) Phospholipid composition of epididymal spermatozoa prepared by density gradient centrifugation. Nature, Lond. 202, 292-293.

Elliot, P. R. (1965) Effect of efferentiectomy and orchidectomy on the metabolism of the epididymis of the mouse. 7. cell. comp. Physiol. 66, 293-301.

Huang, H. F. S. \& Johnson, A. D. (1975) Comparative study of protein pattern of epididymal plasma of mouse, rat, rabbit and sheep. Comp. Biochem. Physiol. (in press).

IaAvon, U., Volcani, R. \& Danon, D. (1971) The proteins of bovine spermatozoa from the caput and cauda epididymidis. J. Reprod. Fert. 24, 219-232.

Lowry, O. H., Rosebrough, N. J., FARR, A. L. \& Randal, , R. J. (1951) Protein measurement with the Folin phenol reagent. F. biol. Chem. 193, 265-275.

Nicander, L. (1965) An electron microscopical study of absorbing cells in the posterior caput epididymidis of rabbits. Z. Zellforsch. mikrosk. Anat. 66, 829-847.

OrGEBIN-GRIST, M.-C. (1969) Studies on the function of the epididymis. Biol. Reprod., Suppl. 1, $155-175$.

Reisfeld, R. A., Lewis, U.J. \& Williams, D. E. (1962) Disc electrophoresis of basic protein and peptides on polyacrylamide gel. Nature, Lond. 195, 281-283.

Turner, P. C. \& Johnson, A. D. (1971) Epididymal lipid of rat with and without testicular contribution. J. Reprod. Fert. 27, 249-255.

Turner, T. T. \& Johnson, A. D. (1973a) The metabolic activity of the bovine epididymis. I. Utilization of glucose and fructose. F. Reprod. Fert. 34, 201-213.

Turner, T. T. \& Johnson, A. D. (1973b) The metabolic activity of the bovine epididymis. II. Utilization of acetate, succinate, pyruvate, lactate and glucose. 7. Reprod. Fert. 35, 445-451.

Waites, G. M. H. \& Setchell, B. P. (1969) Physiology of the testis, epididymis and scrotum. Adv. Reprod. Physiol. 4, 1-63. 